\title{
Comparative Study on Heavy Metal Contamination in Soil, Water and Fodder between Industrial and Non-industrial Areas of Kutch District, Gujarat, India
}

\author{
Bhargavi R. Patel, Hitesh B. Patel, Ratn Deep Singh*, Vaidehi N. Sarvaiya, \\ Mahesh M. Pawar and Shailesh K. Mody
}

Department of Pharmacology and Toxicology, College of Veterinary Science and A. H., Sardarkrushinagar Dantiwada Agricultural University, Sardarkrushinagar- 385506, Banaskantha, Gujarat, India

*Corresponding author

\section{A B S T R A C T}

\section{Keywords}

Heavy metals, Soil, Water, Fodder, Industrial, Nonindustrial, Kutch, Gujarat

\section{Article Info}

Accepted:

15 September 2019

Available Online:

10 October 2019
In present study, heavy metal concentrations of cadmium $(\mathrm{Cd})$, cobalt $(\mathrm{Co})$, chromium $(\mathrm{Cr})$, nickel $(\mathrm{Ni})$, lead $(\mathrm{Pb})$ and copper $(\mathrm{Cu})$ in soil, water and fodder samples collected from industrial (Gandhidham- area 1) and nonindustrial (Bhachau- area 2) areas of Kutch district of Gujarat were determined with objectives to explore presence of heavy metals and correlationship between heavy metal concentrations in environmental components. Comparing the inter-area values, the average level of $\mathrm{Co}$ in non-industrial area and $\mathrm{Cu}$ in industrial area were found significantly higher for soil samples; levels of $\mathrm{Cd}$, $\mathrm{Ni}$ and $\mathrm{Pb}$ collected from non-industrial area were significantly higher as compared to industrial area for water samples while average values of $\mathrm{Cd}$ in industrial area were significantly higher than non-industrial area and average values of $\mathrm{Co}$ in non-industrial area were significantly higher than industrial area for fodder samples. Based on available Maximum Permissible Limit (MPL), none of the soil sample in industrial and non-industrial areas was found to contain heavy metals $(\mathrm{Cd}, \mathrm{Cr}, \mathrm{Pb}$ and $\mathrm{Cu})$ above MPLs.

\section{Introduction}

Heavy metal contamination of the soil, atmosphere and whole environment is a serious issue in areas of intense industries and agriculture where more concentration of these metals shows tendency to accumulate in different environmental components by natural as well as anthropogenic activities. Atmospheric deposition, industrial effluents, artificial fertilizer application and improper waste disposal of plants and animals origin etc. are major problems responsible for heavy metal contamination. The total heavy metal 
content of the soil is commonly used to indicate the degree of contamination but the heavy metal concentration in solution mostly determines the actual environmental exposure or risk (Sherene, 2012).

Industrialization is the major cause for accumulation of pollutants. Use of untreated and treated waste water for agricultural purpose has direct impact on the fertility of soil and the contaminated soil cause risk to the food chain and quality of ground water (Jadhav et al., 2010). Industries create various environmental problems in and around factory areas by discharging untreated or partially treated effluents into the sewers and drains and favour spread on land surfaces. The toxic heavy metals coming from various industries like electroplating, automobile exhaustions and bicycle manufacturing industries entering the ecosystem may lead to geo accumulation, bio-accumulation and bio-magnification (Sherene, 2012). They produce harmful effects on microbial activities in soil and increase pollution (Baath, 1989).

Heavy metal pollution in rural area occurs due to improper disposal of industrial effluents and sewage sludge which cause problem for grazing animals because heavy metals depose on pastures grasses or forages (Smith et al., 1991). Kutch is one of the heavily industrialized districts of Gujarat. The key industries in Kutch include engineering, power, steel pipes, cement and handicrafts. Emerging industry sectors include construction, chemicals, ceramics and textiles. Kutch contributes to over $60 \%$ of Gujarat's salt production which is largely exported to foreign countries. The present investigation on heavy metal assessment in soil, water and fodder was carried out in Kutch district of Gujarat with objective to generate data regarding the presence of heavy metals and to study correlationship between levels of heavy metals in soil, fodder and water.

\section{Materials and Methods}

\section{Study area}

Kutch is the largest district of India, present in Gujarat state with an area of $45,674 \mathrm{~km}^{2}$. It is situated in the South Western corner of the Gujarat between $22.44^{\circ}$ and $24.41^{\circ}$ North Latitude and $78.89^{\circ}$ and $71.45^{\circ}$ East Longitude. Major soil types are medium black, sandy and hydromorphic type. The most common fodder crops grown in Kutch district are bajra, green gram, castor, groundnut, cotton, wheat and moth bean.

\section{Collection of samples}

Samples were collected from two different areas representing industrial (area 1) and nonindustrial area (area 2) namely; Gandhidham and Bhachau. The two areas chosen have a minimum of $30 \mathrm{~km}$ distance between them. Total ten villages were selected five each from industrial area (Gandhidham) and nonindustrial area (Bhachau) for sample collection. From each village six soil, six fodder and six water samples were collected randomly, thus making a total of 60 soil, 60 fodder and 60 water samples from designated areas and the total number of samples collected for entire experiment was 180 (Table $1)$.

Soil samples were obtained from agricultural land used for fodder production, from depth of $0-15 \mathrm{~cm}$ as per standard $\mathrm{V}$ - trench method and stored in clean and dry polythene bags.

Water was collected in a clean and dry plastic container, directly from sources of drinking water for animals at the owner's farm or home. Fodder samples were collected directly from animal farms (storage fodder) which were routinely used for feeding to animal and they were stored in a clean and dry polythene bags. 


\section{Sample digestion}

Exact 10 grams of air dried soil was weighed out using an electronic balance and transferred into a $50 \mathrm{ml}$ conical flask. To this flask, $20 \mathrm{ml}$ of the Diethyl triamine penta-acetic acid (DTPA) extracting solution was added. The suspension was mixed thoroughly using a mechanical shaker for 2 hours with a speed of 120 cycles per minute. The suspension was then filtered with Whatman Paper No. 41 (Tandon, 1993). The filtered sample was stored in dry and clean centrifuge tube (prior washed with deionised water) for temporary storage until final analysis was done. Water samples were analysed directly, without any further treatment (Mwegoha and Kihampa, 2010).

The dried and powdered fodder samples were digested with $10 \mathrm{ml}$ tri-acid mixture $\left(\mathrm{HNO}_{3}\right.$ : $\mathrm{H}_{2} \mathrm{SO}_{4}: \mathrm{HClO}_{4}$ ) in ratio of 10:1:4 (v/v) (Jones et al., 1991). Tri-acid mixture $(600 \mathrm{ml})$ was prepared by mixing nitric acid $(400 \mathrm{ml})$, sulphuric acid $(40 \mathrm{ml})$ and perchloric acid $(160 \mathrm{ml})$ in a glass beaker and allowed to cool and then stored in a glass stoppered reagent bottle. About 0.5 gram of dry and powdered fodder was taken in flask and $10 \mathrm{ml}$ of the triacid mixture was added. It was mixed well and kept over-night at room temperature.

On next day, the mixture was heated for digestion at $180-200^{\circ} \mathrm{C}$ on the electric hot plate until dense white fumes of acids were evolved and a clean colourless solution/ aliquot was obtained. Likewise, all samples were digested till the volume was reduced to 1-2 $\mathrm{ml}$ and allowed to dry. The samples were allowed to cool down and the content was dissolved with $20 \mathrm{ml}$ of distilled water.

The sample was filtered with Whatman Paper No. 41 and stored in dry and clean centrifuge tube (prior washed with deionised water) for temporary storage until analysis.

\section{Instrumentation}

The concentrations of six heavy metals viz. $\mathrm{Cd}, \mathrm{Co}, \mathrm{Cr}, \mathrm{Ni}, \mathrm{Pb}$ and $\mathrm{Cu}$ were determined with Atomic Absorption Spectrophotometer (ECIL, Electronics Corporation of India Limited, Model AAS4141). The hollowcathode lamps for $\mathrm{Cd}, \mathrm{Co}, \mathrm{Cr}, \mathrm{Ni}, \mathrm{Pb}$ and $\mathrm{Cu}$ (Photron $\left.{ }^{\circledR}\right)$ were employed as radiation source. The fuel used was a mixture of air and acetylene gas. Standard solutions prepared by appropriate dilution of the stock solution 10 $\mathrm{mg} / \mathrm{L}$ was used to calibrate the device by means of the standard curve method (Desai et al., 2018).

\section{Quality Assurance}

Appropriate quality assurance procedures and precautions were taken to ensure the reliability of the results. Blank standards and distilled water were also checked before the analysis. In addition, samples were carefully handled to avoid any kind of chemical contamination. Moreover, the glasswares were properly cleaned, and reagents used were of extra-pure/ analytical grades. The deionized water was used throughout the study. Every time standards were run prior to sample run in the AAS.

\section{Statistical analysis}

The significance of the difference between two sampling areas was tested using analysis of variance (one way ANOVA). The impact of industrialization on concentration of heavy metals in soil, water and fodder was tested by employing appropriate statistical procedure using SPSS version 16.0 software for Windows ${ }^{\circledR}$.

\section{Results and Discussion}

The mean $\pm \mathrm{SE}$ values $(\mathrm{mg} / \mathrm{L})$ of $\mathrm{Cd}, \mathrm{Co}, \mathrm{Cr}$, $\mathrm{Ni}, \mathrm{Pb}$ and $\mathrm{Cu}$ in soils from area 1 and area 2 
are summarized in Table 2. In the present study, the average value of $\mathrm{Co}$ in soil was found to be significantly higher $(\mathrm{P}<0.01)$ in area 2 as compare to area 1 . The natural and anthropogenic factors cause soil pollution which affect environment. The scattered presence of brick kilns around sampling areas may be attributed to such results (Porshad et al., 2017).

The mean concentration of $\mathrm{Cu}$ was observed to be higher in area 1 than area 2. Such variation in the $\mathrm{Cu}$ levels in area 1 and 2 can be justified on the basis of presence of many industrial units related to metal, glass, paints, chemical, and ceramics. However, $\mathrm{Cr}$ and $\mathrm{Pb}$ differed non-significantly $(\mathrm{P}>0.05)$ in the soil samples collected from both the areas. Similar studies on the levels of heavy metals in soil were reported in Madhya Pradesh (Rathor et al., 2017; Ahirwar et al., 2018) and Andhra Pradesh (Devasena et al., 2012; Ramesh et al., 2014). The heavy metals analysis with similar trend of results in soil of industrial area is also reported abroad in sawmill industries in Ekiti State, Nigeria (Ezekiel et al., 2013).

The concentrations of heavy metals in water in present study are shown in Table 3. The residue levels of $\mathrm{Cd}, \mathrm{Ni}$ and $\mathrm{Pb}$ in water were observed to be significantly higher $(\mathrm{P}<0.01)$ in area 2 than area 1 and $\mathrm{Co}, \mathrm{Cr}$ and $\mathrm{Cu}$ differed non-significantly $(\mathrm{P}>0.05)$ in both the areas.

Similar result of high level of heavy metals in water was reported in Andhra Pradesh (Ramesh et al., 2014) and reported at abroad in small-scale mining communities of Nangodi and Tinga in northern Ghana (Cobbina et al., 2015), marble industries in Khairabad, District Nowshera, Khyber Pakhtunkhwa, Pakistan (Khan et al., 2017) and abandoned $\mathrm{Pb}-\mathrm{Zn}$ mines in Yelu in Bauchi State, Northern Nigeria (Sanusi et al., 2017). Ojekunle et al., (2016) reported the high mean concentration of $\mathrm{Cd}(0.0121 \mathrm{mg} / \mathrm{L})$, above the maximum permissible value of Standard Organization of Nigeria standards for drinking water Standard Organization of Nigeria (SON, 2007) and World Health Organization (WHO, 2004). In present study, the concentration of lead $(\mathrm{Pb})$ was present in two samples out of the fifteen water samples with a mean value of $0.0324 \mathrm{mg} / \mathrm{L}$. The mean concentrations of $\mathrm{Cu}$ $(0.0341 \mathrm{mg} / \mathrm{L})$ was found to be lower than the highest permissible value, mentioned in the guideline, while no traces of $\mathrm{Ni}$ were found in the water samples across the two sampling locations. Mean concentrations of fodder samples for presence of heavy metals are presented in Table 4. It is indicated that the values $(\mathrm{mg} / \mathrm{L})$ of $\mathrm{Cd}$ was significantly higher $(\mathrm{P}<0.01)$ in area 1 than their corresponding values in area 2 . The higher values of $\mathrm{Cd}$ and $\mathrm{Cu}(\mathrm{mg} / \mathrm{L})$ in area 1 could be attributed to presence of large, small and medium scale industrial units in sampling areas.

However, the values $(\mathrm{mg} / \mathrm{L})$ of Co in fodder samples of area 2 was significantly higher $(\mathrm{P}<0.01)$ than their corresponding values $(\mathrm{mg} / \mathrm{L})$ in area 1 and higher levels of $\mathrm{Co}$ in area 2 could not be correlated with degree of industrialization. The values of $\mathrm{Co}$ and $\mathrm{Cd}$ recorded in present study were in agreement of values reported by Ahmad et al., (2013) for Cd, Bhanderi et al., (2014) for Co, Petukhov (2016) for Cd and Malik et al., (2017) for Cd. Higher concentration of Co in different fodder species was also recorded by Ahmad et al., (2011).

However, concentrations of $\mathrm{Cr}, \mathrm{Ni}$ and $\mathrm{Pb}$ were found to be non-significantly $(\mathrm{P}>0.05)$ different in area 1 and 2 . In present study, $\mathrm{Cd}$ in area 1 while $\mathrm{Pb}$ in both area 1 and 2 in fodder samples were above MPL of respective metals as recommended by the Joint FAO/WHO Expert Committee on Food Additives (1999) and Codex Alimentarius Commission (CAC, 1991) (Cd $0.2 \mathrm{mg} / \mathrm{L}, \mathrm{Pb}$ $0.3 \mathrm{mg} / \mathrm{L}, \mathrm{Cu} 40 \mathrm{mg} / \mathrm{L})$. 
Table.1 Details of sample collection in Kutch district

\begin{tabular}{|c|c|c|c|c|c|c|c|}
\hline Area & $\begin{array}{c}\text { Nature of } \\
\text { area }\end{array}$ & Taluka & Village & Soil & Fodder & Water & Total \\
\hline \multirow{5}{*}{ A1 } & \multirow{5}{*}{ Industrial } & \multirow{5}{*}{ Gandhidham } & $\begin{array}{c}\text { Javaharnaga } \\
\mathrm{r}\end{array}$ & 6 & 6 & 6 & 18 \\
\hline & & & Padana & 6 & 6 & 6 & 18 \\
\hline & & & Galpadar & 6 & 6 & 6 & 18 \\
\hline & & & Antarajal & 6 & 6 & 6 & 18 \\
\hline & & & Rajnagar & 6 & 6 & 6 & 18 \\
\hline \multirow{5}{*}{ A2 } & \multirow{5}{*}{ Non-industrial } & \multirow{5}{*}{ Bhachau } & Laliyana & 6 & 6 & 6 & 18 \\
\hline & & & Vondh & 6 & 6 & 6 & 18 \\
\hline & & & Samkhiyari & 6 & 6 & 6 & 18 \\
\hline & & & Vijpasar & 6 & 6 & 6 & 18 \\
\hline & & & Lunava & 6 & 6 & 6 & 18 \\
\hline Total & 2 & 2 & 10 & 60 & 60 & 60 & 180 \\
\hline
\end{tabular}

Table.2 Inter-area comparison of mean $\pm \mathrm{SE}$ values of $\mathrm{Cd}, \mathrm{Co}, \mathrm{Cr}, \mathrm{Ni}, \mathrm{Pb}$ and $\mathrm{Cu}(\mathrm{mg} / \mathrm{L})$ in soil samples collected from Kutch district

\begin{tabular}{|c|c|c|}
\hline \multirow{2}{*}{ Metal } & \multicolumn{2}{|c|}{ Concentration $(\mathbf{m g} / \mathbf{L})$ Mean \pm SE } \\
\cline { 2 - 3 } & Area-1 $(\mathbf{n}=\mathbf{3 0})$ & Area-2 $(\mathbf{n}=\mathbf{3 0})$ \\
\hline $\mathbf{C d}$ & $0.021 \pm 0.012$ & $0.000 \pm 0.000$ \\
\hline $\mathbf{C o}$ & $0.019 \pm 0.017$ & $0.126 \pm 0.011^{* *}$ \\
\hline $\mathbf{C r}$ & $0.033 \pm 0.030$ & $0.379 \pm 0.182$ \\
\hline $\mathbf{N i}$ & $0.000 \pm 0.000$ & $0.000 \pm 0.000$ \\
\hline $\mathbf{P b}$ & $0.000 \pm 0.000$ & $0.232 \pm 0.194$ \\
\hline $\mathbf{C u}$ & $1.647 \pm 0.111^{* *}$ & $0.447 \pm 0.015$ \\
\hline
\end{tabular}

Table.3 Inter-area comparison of mean $\pm \mathrm{SE}$ values of $\mathrm{Cd}, \mathrm{Co}, \mathrm{Cr}, \mathrm{Ni}, \mathrm{Pb}$ and $\mathrm{Cu}(\mathrm{mg} / \mathrm{L})$ in water samples collected from Kutch district

\begin{tabular}{|c|c|c|}
\hline \multirow{2}{*}{ Metal } & \multicolumn{2}{|c|}{ Concentration $(\mathbf{m g} / \mathbf{L})$ Mean \pm SE } \\
\cline { 2 - 3 } & Area-1 $(\mathbf{n}=\mathbf{3 0})$ & Area-2 $(\mathbf{n}=\mathbf{3 0})$ \\
\hline $\mathbf{C d}$ & $0.009 \pm 0.004$ & $2.152 \pm 0.587^{* *}$ \\
\hline $\mathbf{C o}$ & $0.000 \pm 0.000$ & $0.000 \pm 0.000$ \\
\hline $\mathbf{C r}$ & $0.202 \pm 0.057$ & $0.654 \pm 0.321$ \\
\hline $\mathbf{N i}$ & $0.000 \pm 0.000$ & $1.021 \pm 0.162^{* *}$ \\
\hline $\mathbf{P b}$ & $0.000 \pm 0.000$ & $2.454 \pm 0.340^{* *}$ \\
\hline $\mathbf{C u}$ & $0.129 \pm 0.021$ & $0.122 \pm 0.031$ \\
\hline
\end{tabular}


Table.4 Inter-area comparison of mean $\pm \mathrm{SE}$ values of $\mathrm{Cd}, \mathrm{Co}, \mathrm{Cr}, \mathrm{Ni}, \mathrm{Pb}$ and $\mathrm{Cu}(\mathrm{mg} / \mathrm{L})$ in fodder samples collected from Kutch district

\begin{tabular}{|c|c|c|}
\hline \multirow{2}{*}{ Metal } & \multicolumn{2}{|c}{ Concentration $(\mathbf{n}=60)$} \\
\cline { 2 - 3 } & Area-1 $\left(\mathbf{n}_{\mathbf{1}}=\mathbf{3 0}\right)$ & Area-2 $\left(\mathbf{n}_{\mathbf{2}}=\mathbf{3 0}\right)$ \\
\hline $\mathbf{C d}$ & $0.118 \pm 0.011^{* *}$ & $0.000 \pm 0.000$ \\
\hline $\mathbf{C o}$ & $0.219 \pm 0.025$ & $0.514 \pm 0.052 * *$ \\
\hline $\mathbf{C r}$ & $0.052 \pm 0.026$ & $0.720 \pm 0.388$ \\
\hline $\mathbf{N i}$ & $0.000 \pm 0.000$ & $0.021 \pm 0.009$ \\
\hline $\mathbf{P b}$ & $2.116 \pm 0.225$ & $2.668 \pm 0.432$ \\
\hline $\mathbf{C u}$ & $0.194 \pm 0.022^{*}$ & $0.132 \pm 0.020$ \\
\hline * Significant at level $(\mathrm{P}<0.05)$ and $* *=$ highly significant at level $(\mathrm{P}<0.01)$
\end{tabular}

The most significant outcome of the study indicated that none of soil sample collected from sampling areas showed concentration $(\mathrm{mg} / \mathrm{L})$ of $\mathrm{Cd}, \mathrm{Cr}, \mathrm{Pb}$ and $\mathrm{Cu}$ exceeding MPL of respective metal for soil as recommended by European Commission (EC, 2006) (Cd 3.0 $\mathrm{mg} / \mathrm{L}, \mathrm{Cr} 150 \mathrm{mg} / \mathrm{L}, \mathrm{Pb} 300 \mathrm{mg} / \mathrm{L}, \mathrm{Cu} 140$ $\mathrm{mg} / \mathrm{L})$. The most of samples demonstrated slightly high levels of $\mathrm{Cd}, \mathrm{Cr}, \mathrm{Pb}$ and $\mathrm{Cu}$ in water in area 1 and 2. Disposal of industrial wastage to the area near by water sources might be the cause of contamination of water sources and high levels of metals in study area. Large numbers of brick kilns, coal producing units, automobile hubs, petrol and diesels depot located in sampling areas were evident during sample collection. Brick kiln uses huge amount of coal and rubber tires as a fuel for manufacturing brick in non scientific way leading to adverse effect on environment by emitting metals like chromium and lead (GWRTAC, 1997; Wuana and Okieimen, 2011). Similar findings with respect to level of $\mathrm{Cd}, \mathrm{Cr}$ and $\mathrm{Pb}$ in water were reported in Karnaphuli river, Chittagong city, close to the Bay of Bengal, Bangladesh. It was found that level of $\mathrm{Cd}, \mathrm{Cr}$ and $\mathrm{Pb}$ were higher than prescribed by WHO standard level for drinking water (Ali et al., 2016).

The degree of industrialization could be correlated to presence of heavy metals quantitatively in some instances, while the presence of higher values of metals in area 2 is an exception to this correlation. This suggests that beyond the industrialization and urbanization, the anthropogenic activities, soil type and natures etc., also have impact in metal contamination of soil, water and fodder.

\section{Acknowledgement}

Authors are thankful to the ICAR for providing financial assistance to carry out research work under the ICAR sponsored outreach programme on Monitoring of drug residues and environmental pollutants.

\section{References}

Ahirwar, N. K., G. Gupta, R. Singh and Singh, V. 2018. Assessment of present heavy metals in industrial affected soil area of Mandideep, Madhya Pradesh, India. Int. J. Curr. Microbiol. App. Sci. 7: 2319-7706.

Ahmad, K. A., M. U. Shaheen, Z. I. Khan and Bashir, H. U. 2013. Heavy metals contamination of soil and fodder: a possible risk to livestock. Sci. Technol. Dev. 32(2): 140-148.

Ahmad, K., M. Ibrahim, Z. I. Khan, Y. Rizwan, A. Ejaz, A. Fardsous and AlYemeni, M. 2011. Effect of sewage water on mineral nutritive potential of six fodder species grown under 
semiarid conditions. Saudi J. Biol. Sci. 18(4): 317-321.

Ali, M. M., M. L. Ali, M. S. Islam and Rahman, M. Z. 2016. Preliminary assessment of heavy metals in water and sediment of Karnaphuli River, Bangladesh. Environ. Nanotech. Monit. Manage. 5: 27-35.

Baath, E., 1989. Effects of heavy metals in soil on microbial processes and population (A Review). Water Air Soil Poll. 47: 335-379.

Bhanderi, B. M., M. R. Garg and Sherasia, P. L. 2014. Mineral status of feeds, fodder and dairy animals in Jalgaon district of Maharashtra state. Scholars J. Agric. Vet. Sci. 1(4A): 222-226.

CAC, 1991. Joint FAO/WHO Food Standards Program, Nineteenth Session, 1-10 July 1991, Rome (Codex Alimentarius Commission).

Cobbina, S. J., A. B. Duwiejuah, R. Quansah, S. Obiri and Bakobie, N. 2015. Comparative assessment of heavy metals in drinking water sources in two small-scale mining communities in northern Ghana. Int. J. Environ. Res. Public Health. 12(9): 10620-10634.

Desai, R. R., H. B. Patel, R. D. Singh, V. N. Sarvaiya, M. M. Pawar and Mody, S. K. 2018. Heavy metal concentrations with regard to inter-species variation in cattle and buffalo milk collected from different areas of North Gujarat. Int. J. Curr. Microbiol. App. Sci. 7(8): 17741782.

Devasena, B., J. V. Ramana, P. E. Prasad, S. Sudheer and Prasad, J. R. 2012. Chromium concentration in soil, feeds and plasma of animals in Chittoor District of Andhra Pradesh. Indian J. Anim. Sci. 4: 384-387.

EC, 2006. Council regulation (EC) No.1881/2006 setting maximum levels for certain contaminants in food stuffs via the amending Commission
Regulation. (European Commission).

Ezekiel, A. K., A. O. Samuel, A. S. Sunday and Irenosen, O. G. 2013. Determination of heavy metals in soil samples of selected Sawmills in Ekiti State, Nigeria. J. Sci. Res. Rep. 2(2): 513-521.

GWRTAC, 1997. Remediation of metalscontaminated soils and groundwater," GWRTAC-E Series TE-97-01 (Gujarat Water Resources Development Corporation).

Jadhav, J. P., D. C. Kalyani, A. A. Telke, S. S. Phugare and Govindwar, S. P. 2010. Valuation of the efficiency of a bacterial consortium for the removal of color reduction of heavy metals and toxicity of textile dye water. Bioresour Technol. 101: 165-173.

Joint FAO/WHO Expert Committee on Food Additives, 1999. Toxicological evaluation of certain food additives. ILSI Press International Life Sciences Institute, Geneva.

Jones Jr., J. B., B. Wolf and Mills, H. A. 1991. Plant Analysis Handbook: A Practical Sampling, Preparation, Analysis and Interpretation Guide. Micro-Macro Publishing Inc. Athens, Georgia, USA. pp. 213.

Khan, S. A., M. Suleman and Asad, M. 2017. Assessment of pollution load in marble waste water in Khairabad, District Nowshera, Khyber Pukhtunkhwa, Pakistan. Int. J. Econ. Env. Geol.. 8(2): 35-39.

Malik, A., S. Jadoon, M. Arooj and Latif, M. I. 2017. Assessment of heavy metals in fodder crops leaves being raised with hudiara drain water (Punjab-Pakistan). Int.J. Adv. Eng. Res. Technol. 4(5): 93102.

Mwegoha, W. J., and Kihampa, C. 2010. Heavy metal contamination in agricultural soils and water in dares Salaam city, Tanzania. Afr. J. Environ. 
Sci. Technol. 4(11): 763-769.

Ojekunle, O. Z., O. V. Ojekunle, A. A. Adeyemi, A. G. Taiwo, O. R. Sangowusi, A. M. Taiwo and Adekitan, A. A. 2016. Evaluation of surface water quality indices and ecological risk assessment for heavy metals in scrap yard neighbourhood. Springer Plus. 5(1): 560.

Petukhov, V., 2016. Cadmium level in soil, coarse fodder, organs and tissue of cattle in West Siberia. In: proceedings of the 18th International Conference on Heavy Metals in the Environment held in Ghent, Belgium.

Porshad, R., S. Ahmed, M. Rahman and Kumar, T. 2017. Apportionment of hazardous elements in agricultural soils around the vicinity of brick kiln in Bangladesh. J. Environ. Anal. Toxicol. 7: 439.

Ramesh, S., D. Nagalakshmi, Y. R. Reddy and Reddy, A. R. 2014. Mineral status of soils, water, feeds and fodders of dairy animals in Mahaboobnagar district of Andhra Pradesh. Global J. Bio-sci. Biotechnol. 3: 273-277.

Rathor, G., N. Chopra, T. Adhikari and Aher, S. B. 2017. Heavy metal contamination in soils surrounding Mandideep industrial area, Madhya Pradesh. Asian J. Soil Sci. 12: 30-36.

Sanusi, K. A., M. S. Hassan, M. A. Abbas and Kura, A. M. 2017. Assessment of heavy metals contamination of soil and water around abandoned $\mathrm{Pb}-\mathrm{Zn}$ mines in Yelu, Alkaleri Local Government Area of Bauchi State, Nigeria. Int. Res. J. Public Environ. Health. 4(5): 72-77.

Sherene, T., 2012. Spatial prediction and characterization of heavy metal pollution in soils of Coimbatore district using surfer package. Res. J. Chem. Environ.16: 65-72.

Smith, R. M., R. M. Leach, L. D. Muller, L. C. Griel and Baker, D. E. 1991. Effect of long-term dietary cadmium chloride on tissue, milk, and urine mineral concentrations of lactating dairy cows. J. Anim. Sci. 66: 4088-4096.

SON, 2007. Standards for drinking water quality publications Nigerian (Standards Organization of Nigeria). Pdf Available at www.unicef.org/nigeria/ng accessed on $23^{\text {rd }}$ April, 2018.

Tandon, H. L., 1993. Methods of analysis of soils, plants, waters and fertilizers. Fertilisers Development and Consultation Organisation, New delhi, India. pp. 36-48.

WHO, 2004. Guidelines for drinking water quality: incorporating 1 st and 2nd Addlenda. (World Health Organization, Geneva).

Wuana, R. A., and Okieimen, F. E. 2011. Heavy metals in contaminated soils: a review of sources, chemistry, risks and best available strategies for remediation. ISRN Ecol. 2011: 1-20.

\section{How to cite this article:}

Bhargavi R. Patel, Hitesh B. Patel, Ratn Deep Singh, Vaidehi N. Sarvaiya, Mahesh M. Pawar and Shailesh K. Mody. 2019. Comparative Study on Heavy Metal Contamination in Soil, Water and Fodder between Industrial and Non-industrial Areas of Kutch District, Gujarat. Int.J.Curr.Microbiol.App.Sci. 8(10): 2096-2103. doi: https://doi.org/10.20546/ijcmas.2019.810.244 